\title{
Rituximab during pregnancy in neuromyelitis optica: A case report
}

Jahir Miranda-Acuña, MD, Erica Rivas-Rodríguez, MD, Michael Levy, MD, PhD, Mustafa Ansari, MS, Roslynn Stone, PharmD, PhD, Vivek Patel, MD, and Lilyana Amezcua, MD, MS

Neurol Neuroimmunol Neuroinflamm 2019;6:e542. doi:10.1212/NXI.0000000000000542

Neuromyelitis optica spectrum disorder (NMOSD) is a rare autoimmune disorder of the CNS, which predominantly targets the optic nerves and spinal cord leading to blindness and paralysis. ${ }^{1}$ There is a 6-9:1 ratio affecting females far more often than males, and there is an increased risk of relapse during and immediately after pregnancy. ${ }^{2}$ B-cell depletion therapy has been reported to prevent rebound in postpartum relapses. ${ }^{3,4}$ In this report, we describe the safety and clinical effect of B-cell depletion in both the patient and her infant baby.

\section{Clinical report}

At 1-month postpartum, a 33-year-old Japanese American female developed a lower thoracic sensory level and lower extremity motor weakness from a longitudinally extensive transverse myelitis from T2 to T4. She developed bilateral optic neuritis 2 months later and tested seropositive for the aquaporin-4 (AQP4) antibody with a titer $>160 \mathrm{U} / \mathrm{mL}$ by ELISA followed by cell-based assay and performed by ATHENA diagnostics. She was diagnosed with NMOSD, and IV rituximab infusions were started using standard dosing of 1,000 $\mathrm{mg}$ infused twice with 2 weeks between doses. She remained clinically stable and conceived 3 months after last rituximab infusion with corresponding \%CD19 + count $<1 \%$ and an NMO titer of $14.1 \mathrm{U} / \mathrm{mL}$ (figure, A). Because of the severity of her postpartum relapses and personal experience, a physician-patient informed decision was made to continue rituximab throughout pregnancy.

\section{Pregnancy course}

B-cell depletion was maintained essentially at zero throughout pregnancy (figure, A). Optical coherence tomography was performed during pregnancy and followed very same principles emphasized in the OSCAR-IB methodology as were prior measures. ${ }^{5}$ Subclinical thinning of the ganglion cell-inner plexiform (GCIP) layer compared to baseline was also noted in the left eye (figure, B) during her neuro-ophthalmologic visit before infusion. Infusion of rituximab of $1,000 \mathrm{mg}$ was given at 24 weeks of pregnancy. The rest of her pregnancy was clinically unremarkable under the care of a high-risk obstetrician and she delivered a healthy male at 38week gestation via vaginal delivery.

\section{Infant and maternal outcome}

Appearance, Pulse, Grimace, Activity, Respiration scores were normal and the infant's \%CD19 + cells were $1 \%$ at birth. At 2 months, the infant's \%CD19 + count rose to $23 \%$. As a result, no change in the infant's vaccination schedule was made and standard vaccinations were given. No

\author{
Correspondence \\ Dr. Amezcua \\ lamezcua@usc.edu
}


Figure (A) Longitudinal measurements of NMO AQP4 antibody titer and CD19 cell counts before, during, and after pregnancy demonstrating declining AQP4 antibody titer and near complete B-cell depletion, along with rituximab infusions from 2015 to 2018

A

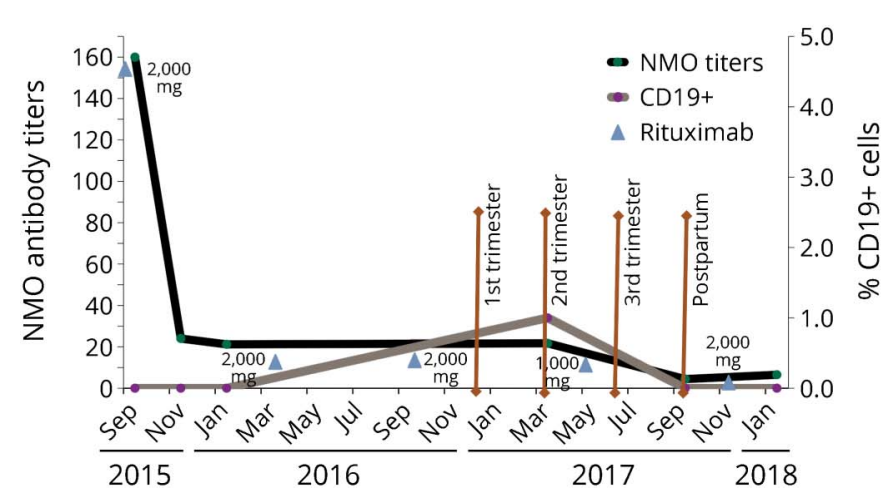

B

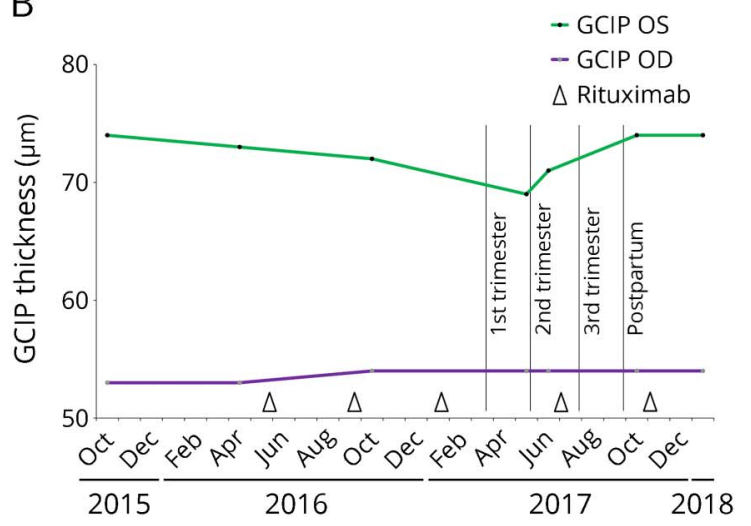

(B) Using optical coherence tomography, the thickness of the GCIP layers of both eyes were followed before, during, and after pregnancy (2015-2018). We noted subclinical thinning within this layer in her better eye during pregnancy, which returned to baseline thickness after delivery. GCIP = ganglion cell-inner plexiform; NMO = neuromyelitis optica.

infections, normal development, and normal B-cell counts were reported at 6-month follow-up. AQP4 antibody testing in the infant's serum was negative.

As for the mother, post-delivery follow-up revealed her to be well and her physical examination to be stable. She was continued on rituximab. No neurologic or infectious sequelae at the 6-month follow-up were reported. GCIP thickness of her left eye returned to baseline when evaluated at 4 months postpartum (figure, B).

\section{Discussion}

We describe the clinical outcome of using rituximab in a patient with NMOSD during pregnancy, which appeared safe and well tolerated both to mother and infant. Treatment with B-cell depleting therapy in NMO during pregnancy is controversial because of scarce data. ${ }^{2,3}$ Nevertheless, as prior studies have shown, the annualized relapse rate of 1.8 in patients with postpartum NMOSD is substantially higher than preceding pregnancy. ${ }^{6}$ The decision to continue the patient on rituximab through pregnancy was made to reduce the risk of relapse. Interestingly, progressive thinning of the GCIP thinning in NMOSD has been described in prior studies, which was also noted in this case. ${ }^{7}$ Because this patient's GCIP had been stable over time, a thinning of the GCIP during pregnancy could represent changes associated with inflammation and less likely degeneration, because recovery to pre-existing baseline was seen after pregnancy. The GCIP thinned slightly during the time of her pregnancy and recovered its prepregnancy caliber after our patient gave birth. We also found this finding to be interesting and postulate that the transient GCIP thinning could be a result of alterations in the immune environment during pregnancy. Whether GCIP could be used as a marker in pregnancy in NMOSD is unknown.
Previous studies of rituximab exposure during pregnancy in other autoimmune or hematologic conditions have shown that $\% \mathrm{CD} 19+$ levels in the newborn are less than $1 \%$ at birth and tend to recover to normal levels after 6-8 weeks. ${ }^{8}$ In our case, \%CD 19 + cells in the newborn were consistent with prior reports with rapid recovery seen by 3 months. ${ }^{8}$ In addition, no infections or other hematologic abnormalities were reported in the newborn. Because of the rapid recovery of the \%CD19 + cell counts, infants exposed to rituximab in utero are expected to have a normal vaccination response. ${ }^{9}$

This case illustrates a favorable outcome in NMOSD and newborn well-being after gestational exposure to rituximab. We suggest that rituximab can be considered during pregnancy when there are increasing concerns and clinical history suggesting a high risk for gestational and postpartum relapse. We also recommend that a multidisciplinary approach should be taken involving neurology, neuro-ophthalmology, highrisk obstetrics, and pediatrics to follow the patient and infant closely.

\section{Author contributions}

J. Miranda-Acuña: drafting of the manuscript, design, editing final text, and review of the literature. E. Rivas-Rodriguez: drafting of the manuscript editing final text and review of the literature. M. Levy: editing, drafting, and reviewing final text. $M$. Ansari: editing final text and review of the literature. $\mathrm{R}$. Stone: editing final text and review of the literature. V. Patel: editing, drafting, and reviewing final text. L. Amezcua: drafting of the manuscript, design, editing final text, and review of the literature.

\section{Study funding}

No targeted funding reported. 


\section{Disclosure}

J. Miranda-Acuña received travel funding from ACTRIMS; E. Rivas-Rodriguez reports no disclosures; $M$. Levy served on the scientific advisory board for Asterias, Chugai, Alexion, served on the editorial board for Multiple Sclerosis and Related Disorders, holds patents for Aquaporin-4 sequence that elicits pathogenic T-cell response in animal model of neuromyelitis optica, patent covers use of peptide for diagnostic and therapeutic developments, consulted for Guidepoint Global, Gerson Lehrman Group, Cowen Group, received research support from Viropharma/Shire, Acorda, ApoPharma, Sanofi, Genzyme, Alnylam, Alexion, Terumo BCT, NINDS, and Guthy-Jackson Charitable Foundation; M. Ansari received speaker honoraria for MS Views and News, received research support from USC Keck Medical Center, National MS Society; R. Stone and V. Patel reports no disclosures; L. Amezuca served on the scientific advisory board for Celgene and Genzyme, participated in a short-film documentary about MS in the Hispanic community, consulted for Celgene and Genzyme, received research support from MedDay, Biogen, NIH NINDS, Guthy-Jackson Charitable Foundation, National MS Society, and California Community Foundation. Full disclosure form information provided by the authors is available with the full text of this article at Neurology.org/NN.

\section{Publication history}

Received by Neurology: Neuroimmunology \& Neuroinflammation September 16, 2018. Accepted in final form December 10, 2018.

\section{References}

1. Wingerchuk DM, Banwell B, Bennett JL, et al. International consensus diagnostic criteria for neuromyelitis optica spectrum disorders. Neurology 2015;85:177-189.

2. Shosha E, Pittock SJ, Flanagan E, Weinshenker BG. Neuromyelitis optica spectrum disorders and pregnancy: interactions and management. Mult Scler 2017;23:1808-1817.

3. Ringelstein M, Harmel J, Distelmaier F, et al. Neuromyelitis optica and pregnancy during therapeutic B cell depletion: infant exposure to anti-AQP4 antibody and prevention of rebound relapses with low-dose rituximab postpartum. Mult Scler 2013; 19:1544-1547.

4. Das G, Damotte V, Gelfand JM, et al. Rituximab before and during pregnancy: a systematic review, and a case series in MS and NMOSD. Neurol Neuroimmunol Neuroinflamm 2018;5:e453. doi: 10.1212/NXI.0000000000000453.

5. Schippling S, Balk LJ, Costello F, et al. Quality control for retinal OCT in multiple sclerosis: validation of the OSCAR-IB criteria. Mult Scler 2015;21:163-170.

6. Shimizu Y, Fujihara K, Ohashi T, et al. Pregnancy-related relapse risk factors in women with anti-AQP4 antibody positivity and neuromyelitis optica spectrum disorder. Mult Scler 2016;22:1413-1420.

7. Oertel FC, Havla J, Roca-Fernandez A, et al. Retinal ganglion cell loss in neuromyelitis optica: a longitudinal study. J Neurol Neurosurg Psychiatry 2018;89:1259-1265.

8. Chakravarty EF, Murray ER, Kelman A, Farmer P. Pregnancy outcomes after maternal exposure to rituximab. Blood 2011;117:1499-1506.

9. Klink DT, van Elburg RM, Schreurs MW, van Well GT. Rituximab administration in third trimester of pregnancy suppresses neonatal B-cell development. Clin Dev Immunol 2008;2008:271363. 


\section{Neurology ${ }^{\oplus}$ \\ Neuroimmunology \& Neuroinflammation}

Rituximab during pregnancy in neuromyelitis optica: A case report

Jahir Miranda-Acuña, Erica Rivas-Rodríguez, Michael Levy, et al.

Neurol Neuroimmunol Neuroinflamm 2019;6;

DOI 10.1212/NXI.0000000000000542

This information is current as of February 1, 2019

Neurol Neuroimmunol Neuroinflamm is an official journal of the American Academy of Neurology.

Published since April 2014, it is an open-access, online-only, continuous publication journal. Copyright

Copyright $\odot 2019$ The Author(s). Published by Wolters Kluwer Health, Inc. on behalf of the American

Academy of Neurology.. All rights reserved. Online ISSN: 2332-7812.

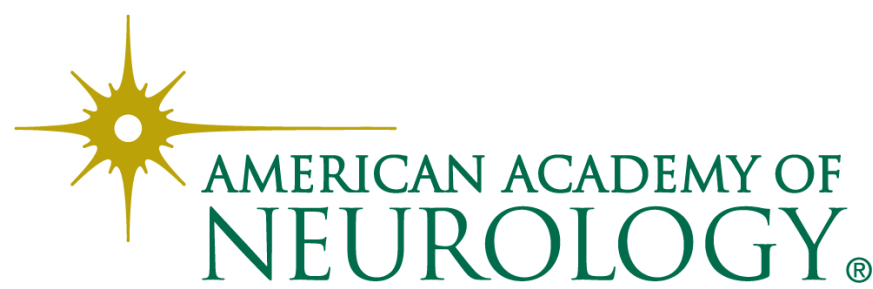




\section{Updated Information \& Services}

References

Citations

Subspecialty Collections

Permissions \& Licensing

Reprints including high resolution figures, can be found at: http://nn.neurology.org/content/6/2/e542.full.html

This article cites 9 articles, 2 of which you can access for free at: http://nn.neurology.org/content/6/2/e542.full.html\#\#ref-list-1

This article has been cited by 3 HighWire-hosted articles: http://nn.neurology.org/content/6/2/e542.full.html\#\#otherarticles

This article, along with others on similar topics, appears in the following collection(s):

All Demyelinating disease (CNS)

http://nn.neurology.org//cgi/collection/all_demyelinating_disease_cns Autoimmune diseases

http://nn.neurology.org//cgi/collection/autoimmune_diseases

Devic's syndrome

http://nn.neurology.org//cgi/collection/devics_syndrome

Prognosis

http://nn.neurology.org//cgi/collection/prognosis

Information about reproducing this article in parts (figures,tables) or in its entirety can be found online at:

http://nn.neurology.org/misc/about.xhtml\#permissions

Information about ordering reprints can be found online:

http://nn.neurology.org/misc/addir.xhtml\#reprintsus

Neurol Neuroimmunol Neuroinflamm is an official journal of the American Academy of Neurology.

Published since April 2014, it is an open-access, online-only, continuous publication journal. Copyright

Copyright $\odot 2019$ The Author(s). Published by Wolters Kluwer Health, Inc. on behalf of the American

Academy of Neurology.. All rights reserved. Online ISSN: 2332-7812.

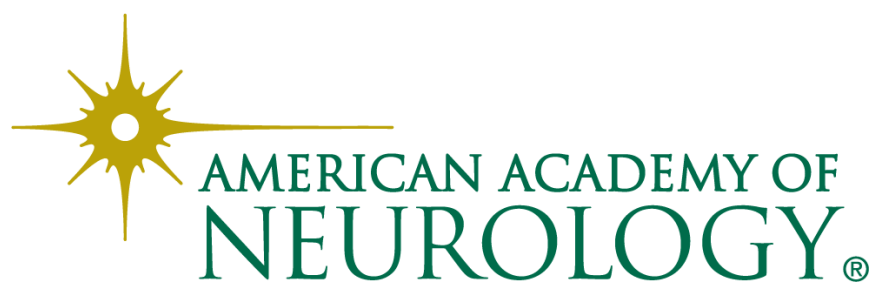

